\title{
BONY LACERATIONS CAUSED BY ASSAULT
}

\author{
L. A. RYMASZEWSKI, J. M. CAULlAY
}

From Glasgow Royal Infirmary

Eight cases of unstable fractures caused by sharp heavy weapons such as swords or machetes are presented. A modern approach to these injuries is described against the historical background.

Compound, displaced fractures of the limbs inflicted by sharp heavy weapons, such as swords or axes, have been treated by surgeons for centuries. In 1672 Richard Wiseman wrote of their essentially defensive nature in his book, $A$ treatise of wounds: "The enemy cruelly hacking them, the poor soldier the while shielding his head with his arms ... until they both be cruelly sutures and splinting the fracture, although apparently at the beginning of the nineteenth century French surgeons preferred to keep the wound open with dry lint (Thomson 1816). Little has been written regarding this subject since the beginning of the twentieth century.

Assaults with such weapons as meat cleavers, machetes, and swords (Fig. 1) appear to have become

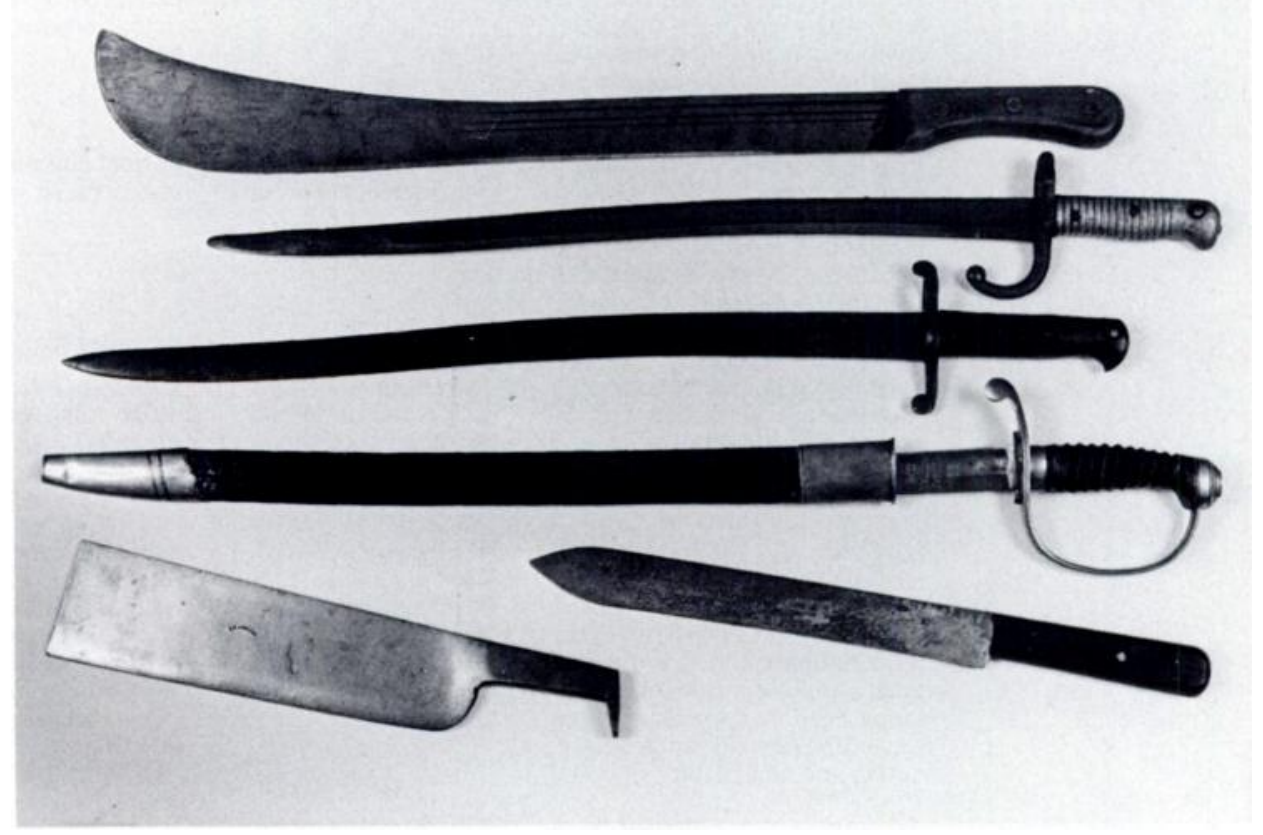

Fig. 1

These weapons, capable of producing "bony laceration", were either confiscated by the police or actually used in assaults: they come from the "Black Museum". Strathclyde Police Headquarters. (By kind permission.)

mangled". However, gunshot wounds dominated military surgery even at that time and by the nineteenth century hand-to-hand fighting was uncommon (Stevenson 1910).

In the eighteenth and nineteenth centuries treatment consisted of closing the wound with plaster dressings or

L. A. Rymaszewski, FRCS, FRCS Ed, Registrar

J. M. Caullay, FRCS Ed, FRCS Glas, Registrar

Accident and Orthopaedic Division, Glasgow Royal Infirmary, Glasgow G4 0SF, Scotland.

Requests for reprints should be sent to Mr L. A. Rymaszewski.

(C) 1984 British Editorial Society of Bone and Joint Surgery $0301-620 X / 84 / 1009 \$ 2.00$ more common in the last few years in Glasgow. On exploration of the majority of these wounds the bone is merely grooved and hence only repair of the soft tissues need be carried out. However, occasionally the weapon actually divides the bone and the fragments are displaced. This report describes our experience of these injuries.

\section{MATERIAL AND METHODS}

Eight cases of "bony lacerations" have been collected over a period of four years at Glasgow Royal Infirmary from 1979 to 1983. Most of these were personally 
Table I. Description of the eight patients

\begin{tabular}{|c|c|c|c|c|c|}
\hline Case & $\begin{array}{l}\text { Age } \\
\text { (years) }\end{array}$ & $\begin{array}{l}\text { Number and site } \\
\text { of wounds }\end{array}$ & Bony laceration & Treatment & Result \\
\hline 1 & 19 & $\begin{array}{l}\text { 9: arms, scalp, hands } \\
\text { and scapula }\end{array}$ & $\begin{array}{l}\text { Two lacerations, posterior aspect } \\
\text { right elbow. Triceps divided. } \\
\text { Upper wound-grooved lateral } \\
\text { condyle humerus. Lower wound- } \\
\text { large bony fragment of capitellum } \\
\text { and half trochlea virtually } \\
\text { detached of soft tissues. No } \\
\text { neurovascular damage }\end{array}$ & $\begin{array}{l}\text { Fragment reduced. } \\
\text { Sherman screw fixation. } \\
6 \text { weeks immobilisation } \\
\text { in a plaster cast }\end{array}$ & $\begin{array}{l}\text { Wound healed by primary } \\
\text { intention. Fracture united. } \\
\text { Screw removed at one year. } \\
\text { Full range of movement apart } \\
\text { from slight limitation of } \\
\text { extension }\end{array}$ \\
\hline $\begin{array}{l}2 \text { (Figs } 2 \\
\text { and 3) }\end{array}$ & 70 & 1 & $\begin{array}{l}\text { Two-inch laceration almost } \\
\text { circumferential, over radial side } \\
\text { hand with division neck second } \\
\text { metacarpal. Tendons intact. No } \\
\text { neurovascular damage }\end{array}$ & $\begin{array}{l}\text { Cross K-wire fixation. } 3 \\
\text { weeks immobilisation in } \\
\text { a plaster cast }\end{array}$ & $\begin{array}{l}\text { Wound healed by primary } \\
\text { intention. Fracture united. } \\
\text { Somewhat stiff finger joints- } \\
\text { half range of flexion at six } \\
\text { months }\end{array}$ \\
\hline $\begin{array}{l}3 \text { (Figs } 4 \\
\text { and 5) }\end{array}$ & 19 & $\begin{array}{l}\text { 8: scalp, left elbow, } \\
\text { right leg }\end{array}$ & $\begin{array}{l}\text { Olecranon divided transversely } \\
\text { with separation of the fragments } \\
\text { and bruising of the articular } \\
\text { surface lower end of humerus. } \\
\text { Detached lateral expansion right } \\
\text { knee with grooving of tibial } \\
\text { condyle, partial detachment } \\
\text { insertion calcaneal tendon with } \\
\text { flake at os calcis }\end{array}$ & $\begin{array}{l}\text { Two K-wires and } \\
\text { tension band wiring. } 6 \\
\text { weeks immobilisation in } \\
\text { a plaster cast }\end{array}$ & $\begin{array}{l}\text { Wound healed by primary } \\
\text { intention. Fracture united. } \\
\text { Virtually full range of } \\
\text { movement with } 5 \text { degrees } \\
\text { extension lag at six months } \\
\text { (wires removed after four } \\
\text { months) }\end{array}$ \\
\hline $\begin{array}{l}4 \text { (Figs } 6 \\
\text { and } 7 \text { ) }\end{array}$ & 29 & 1 & $\begin{array}{l}\text { Penetrating knife injury right } \\
\text { scapula. Blade firmly embedded } \\
\text { through bone, lying below and } \\
\text { medial to shoulder joint. No } \\
\text { pneumothorax. No neurovascular } \\
\text { damage }\end{array}$ & $\begin{array}{l}\text { Knife blade extracted, } \\
\text { debridement of wound }\end{array}$ & $\begin{array}{l}\text { Patient absconded on same day } \\
\text { and not seen again }\end{array}$ \\
\hline $\begin{array}{l}5 \text { (Figs } 8 \\
\text { and 9) }\end{array}$ & 20 & 1 & $\begin{array}{l}\text { Three-inch wound over front of left } \\
\text { knee. Detachment distal bony } \\
\text { insertion patella tendon with } \\
\text { extensive tearing lateral } \\
\text { expansions and bruising articular } \\
\text { surface femoral condyle }\end{array}$ & $\begin{array}{l}\text { Fragment reduced and } \\
\text { fixed with AO } \\
\text { cancellous screw and } \\
\text { washer. } 6 \text { weeks } \\
\text { immobilisation in a } \\
\text { plaster cast }\end{array}$ & $\begin{array}{l}\text { Wound healed by primary } \\
\text { intention. Fracture united. Full } \\
\text { range of movement and no } \\
\text { problems }\end{array}$ \\
\hline 6 & 19 & 1 & $\begin{array}{l}\text { Large wound over flexor and } \\
\text { medial side wrist. Divided: } \\
\text { triquetrum with deep scoring of } \\
\text { lunate; capsule of wrist; all flexor } \\
\text { tendons apart from flexor pollicis } \\
\text { longus and digitorium profundus to } \\
\text { index: median and ulnar nerves } \\
\text { (including dorsal branch ulnar } \\
\text { nerve) and ulnar artery }\end{array}$ & $\begin{array}{l}\text { Triquetrum reduced and } \\
\text { fixed with K-wire. All } \\
\text { structures repaired, } \\
\text { dynamic traction in } \\
\text { plaster slab three weeks }\end{array}$ & $\begin{array}{l}\text { Wound healed by primary } \\
\text { intention. Fracture united. Too } \\
\text { early to assess recovery of } \\
\text { sensation but almost full range } \\
\text { of movement of fingers and } \\
\text { wrist four months after injury. } \\
\text { (K-wire removed after three } \\
\text { months) }\end{array}$ \\
\hline 7 & 17 & $\begin{array}{l}11 \text { : scalp, right ear } \\
\text { almost severed, upper } \\
\text { lumbar region, left } \\
\text { hip, right hand with } \\
\text { four tendons } \\
\text { completely or partially } \\
\text { divided }\end{array}$ & $\begin{array}{l}\text { Acromion process divided and } \\
\text { detached from scapula. Division of } \\
\text { posterior capsule of shoulder and } \\
\text { groove in articular surface of } \\
\text { humerus. Division of spinous } \\
\text { process L2 }\end{array}$ & $\begin{array}{l}\text { Two Sherman screws } \\
\text { used to fix acromion } \\
\text { fracture }\end{array}$ & $\begin{array}{l}\text { Wound healed by primary } \\
\text { intention. Fracture united. Full } \\
\text { range of movement at three } \\
\text { months }\end{array}$ \\
\hline 8 & 20 & $\begin{array}{l}\text { 2: scalp (grooved outer } \\
\text { table of skull), left } \\
\text { shoulder }\end{array}$ & $\begin{array}{l}\text { Left shoulder transverse three-inch } \\
\text { wound with fracture through } \\
\text { posterior aspect of acromion. Bony } \\
\text { fragment pulled distally by deltoid } \\
\text { fibres attached to it }\end{array}$ & $\begin{array}{l}\text { Bone fragment reduced } \\
\text { and fixed with AO screw }\end{array}$ & $\begin{array}{l}\text { Wound healed by primary } \\
\text { intention. Fracture united. Full } \\
\text { range of movement }\end{array}$ \\
\hline
\end{tabular}




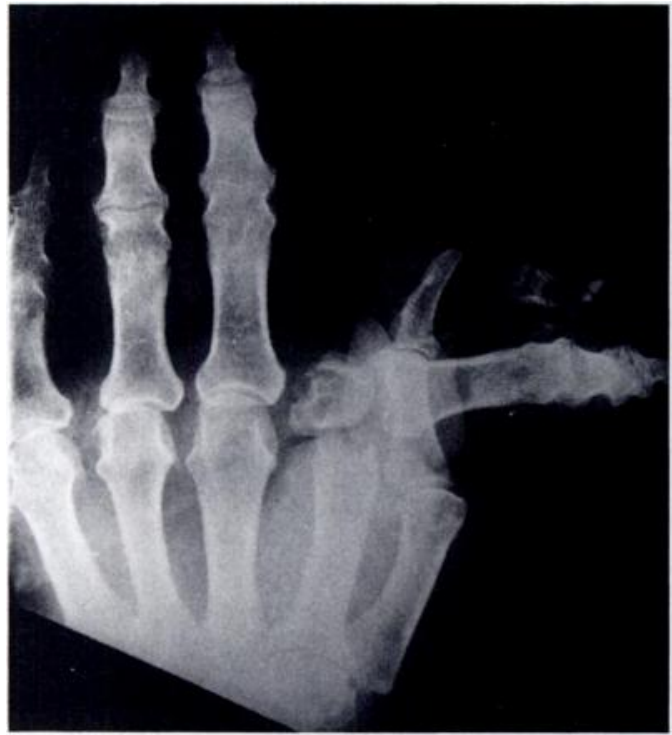

Fig. 2

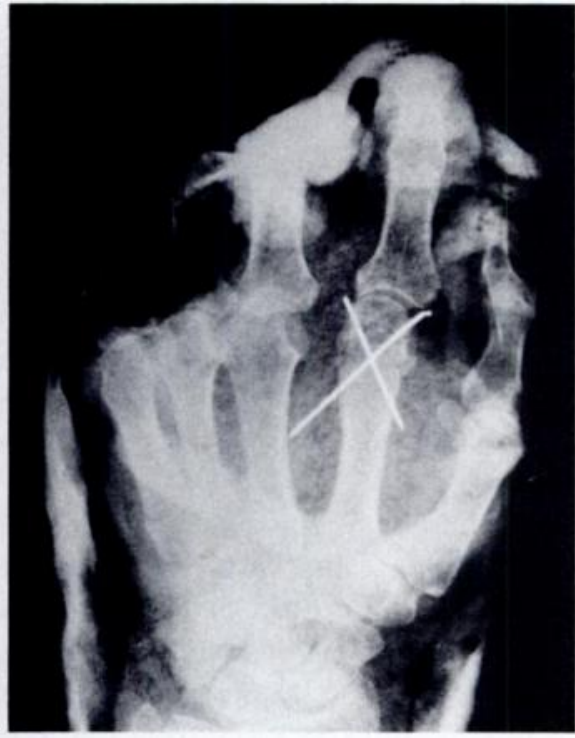

Fig. 3

Figure 2--This was the result of a blow from a meat cleaver; the neck of the second metacarpal has been completely divided. Figure 3-After reduction and fixation with two $\mathrm{K}$-wires.

managed by the authors. All the patients were examined both clinically and radiographically before proceeding to formal exploration as soon as was possible. Prophylactic antibiotic and antitetanus therapy was used routinely. The notes and radiographs were assessed and, where possible, follow-up examinations were carried out. Five of the cases were available for review; three could not be traced.

\section{RESULTS}

The clinical features, treatment and results are summarised in Table I and illustrated in Figures 2 to 9.

\section{DISCUSSION}

Gunshot wounds have dominated military surgery for centuries, whereas injuries due to swords or bayonets have become increasingly uncommon. Of over 246000 casualties in the American Civil War, only 922 sustained

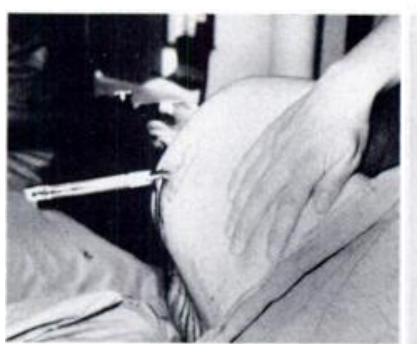

Fig. 6
Figure 6-A heavy fish knife is embedded in the blade of the scapula. Figure 7 -This radiograph shows the position.

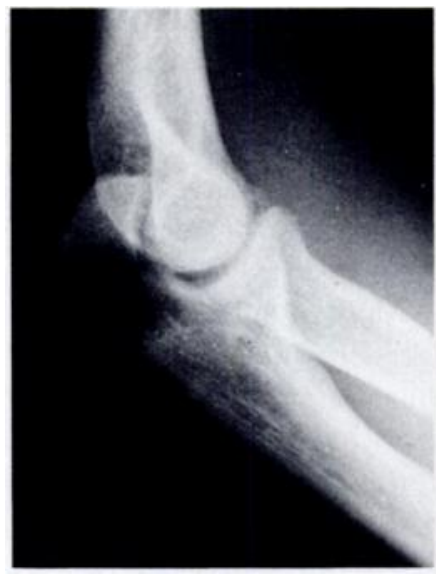

Fig. 4

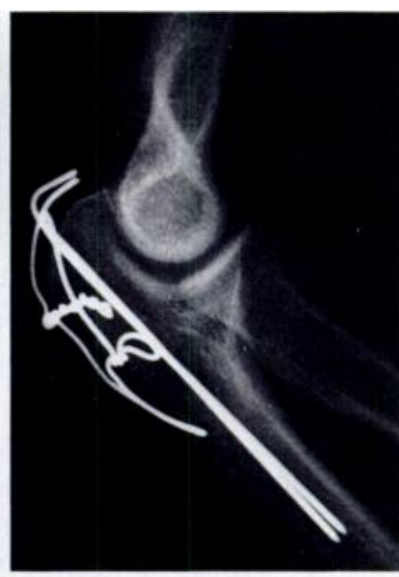

Fig. 5
Figure 4-A machete blow completely divided this olecranon. Figurs 5-After internal fixation with tension band wiring.

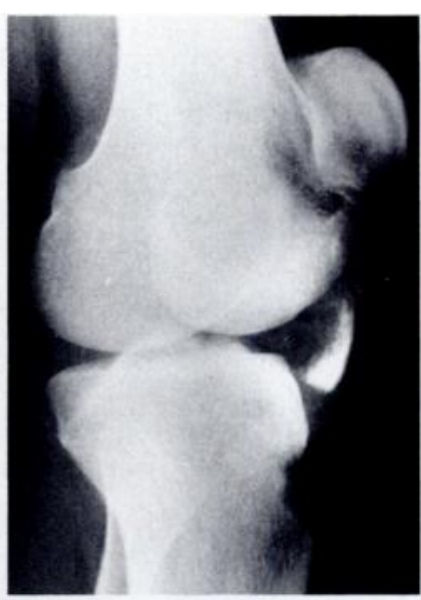

Fig. 8

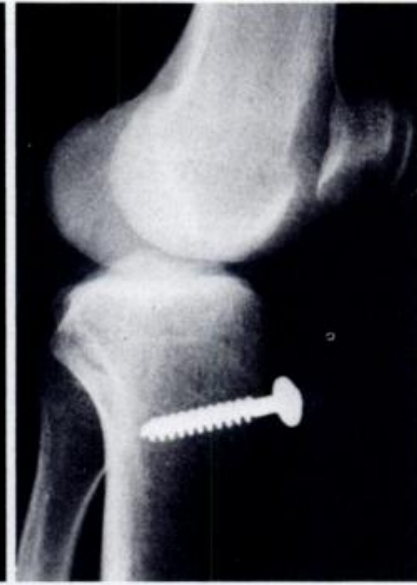

Fig. 9
Figure 8-The insertion of the patellar ligament has been detached by a blow from a machete. Figure 9-After reduction and internal fixation with an $\mathrm{AO}$ cancellous screw. 
such wounds $(0.37$ per cent) (Otis 1883$)$. Similarly in the Franco-Prussian War of 1870 , there were only 600 cases of wounds caused by "cold steel" out of a total of 98000 (0.6 per cent) (Delorme 1915). These injuries would seem relatively trivial to the military surgeon in comparison with the effects of high velocity missiles, and this probably accounts for the paucity of literature on the subject. In this century combat at close quarters has been rare; when it has occurred the wounds were likely to prove fatal (Hamilton Bailey 1942). Hence, we could not find any description of the modern treatment of these injuries.

A report by Hudson and Seton (1895) of two cases of multiple sword wounds is remarkably similar to our own. They described grooving of the skull, a fractured olecranon, a wrist wound involving fracture of the ulna and division of the ulnar artery, a fractured phalanx and a large wound resulting in division of the spines of three cervical and three thoracic vertebrae and the spine of the scapula.

In the nineteenth century several authors compared the blunt, springy European sword which did not have the potential to cleave through a bone, except possibly when wielded whilst on horseback, with the razor-sharp, rigid Oriental weapon, easily capable of cutting straight through a bone. In addition, they pointed out that wounds caused by finely honed swords or long knives produced clean incisions with no evidence of contusion but often of great depth (Forbes-Mitchell 1893; Stevenson 1910). Similarly, in our series, all the wounds were cleanly incised, indicating the sharpness and weight of the weapons used. This results in a diagnostic pitfall, for the examining doctor may be misled by the wound's innocent appearance, unaware of the potential damage to the deep tissues, including fractures. Further, a high index of suspicion must be maintained as a false history may be given; if any doubt exists regarding the circumstances in which a wound has been sustained radiographs are mandatory.
By the end of the nineteenth century treatment consisted of debridement, ligation of vessels, suture of any divided tendons or large nerves and closure of the wound with external splintage of the fracture (Stevenson 1910).

Our management today differs in that we use internal fixation together with antibiotics and tetanus prophylaxis. The wounds lend themselves readily to such treatment as there is minimal soft-tissue damage, often only a guillotine type of injury. Hence, the prognosis when divided muscles, tendons, nerves or vessels are repaired is very good and infection is unlikely. As the bone itself has almost invariably been divided cleanly, with little or no comminution, perfect reduction of the fragments is usually possible and internal fixation is reasonably straightforward. A further argument in favour of fixation is that the smooth bony surfaces are inherently unstable. When plaster casts were utilised, we retained them for longer rather than shorter periods of time, as the patients tended to be unreliable in following instructions. Injuries such as those in our series have a very good prognosis in that both the soft tissues and the bone usually heal well, and good restoration of function is possible in most patients.

Three of our patients could not be traced for this review and hence only their notes and radiographs were utilised. This is not unexpected as the wounds are often received during some illegal activity and in order to avoid being taken into custody the victim may give false information or take his own discharge; non-attendance at clinics is high. In view of this background, the examining doctor should take a full history and carry out a thorough examination with careful notes at the time of presentation, especially as such cases frequently have legal implications.

In conclusion, we present our experience of this unusual type of injury, stressing the importance of a high index of suspicion and the good prognosis after internal fixation.

\section{REFERENCES}

Delorme E. War Surgery, trans. de Méric H. London: HK Lewis, 1915:2.

Forbes-Mitchell W. Reminiscences of the Great Mutiny. London: Macmillan and Co, 1893;286-91.

Hamilton Bailey HH. Surgery of modern warfare. 2nd ed. Edinburgh: E \& S Livingstone, 1942: 18.

Hudson HC, Seton BG. 16th Field Hospital, Waziristan Force, Camp Wano: notes on cases of sword-cut wounds. Br Med J 1895; i 16-7.

Otis GA. The medical and surgical history of the War of the Rebellion. 2nd ed. Washington DC: US Government Printing Office, 1883;Part III, Volume II :685-7.

Stevenson WF. Wounds in war : the mechanism of their production and their treatment. 3rd ed. London: Longmans, Green \& Co, 1910:1-4, 98-9.

Thomson J. Report of observations made in the British Military Hospitals in Belgium after the Battle of Waterloo with some remarks on amputation. Edinburgh: Blackwood, 1816:26-8.

Wiseman R. A treatise of wounds. London: R. Norton, 1672:27. 